\title{
An Analysis of REIT Security Issuance Decisions
}

\author{
Walter I. Boudry, New York University \\ Jarl G. Kallberg, Thunderbolt School of Global Management \\ Crocker H. Liu, Cornell University
}

This article tests the ability of traditional capital structure theories to explain the issuance decisions of real estate investment trusts (REITS). For issuances made between 1997 and 2006, we find strong support for the market timing theory of capital structure. Controlling for past returns and growth, a REIT is more likely to issue equity when its price-to-net asset value ratio is high. This suggests that REITs issue equity in public markets when the cost of equity capital is lower in the public market than in the private market. Consistent with traditional market timing, REITs are more likely to issue equity after experiencing large price increases. We also find some support for REITs following the trade-off theory of capital structure. REITs are less likely to issue debt when proxies for expected bankruptcy costs are high.

Numerous theories explaining a firm's capital structure choices have been posited since the seminal work of Modigliani and Miller (1958). Testing these theories has received extensive attention in the finance literature with mixed results. Indeed, even the idea that extant empirical tests of capital structure are meaningful has been debated; for example, Welch (2004) argues that corporations make little effort to control their capital structure over time, and thus capital structure at any time is merely an outcome of past stock price history.

The current literature has essentially evolved from three competing hypotheses of capital structure: (1) trade-off theory, (2) pecking-order theory and (3)market timing. ${ }^{1}$ Trade-off theory predicts that a firm's capital structure choice will be the outcome of the interaction between the benefits of debt and bankruptcy costs. That is, an optimal capital structure exists where the marginal costs and benefits of additional debt are equal. Whenever the firm's capital structure is away from this level it should converge toward it.

\footnotetext{
${ }^{1}$ Another theory of capital structure deals with how managers can use leverage to signal the firm type. However, as Ross (1977) notes, the comparative statics and empirical implications of this theory do not easily apply in a dynamic setting.
} 
Pecking-order theory (see, e.g., Myers 1984, Myers and Majluf 1984) predicts that, due to information asymmetry between managers and the capital market, markets will penalize firms for issuing securities that are most sensitive to this information. Because of this, firms will choose to issue securities in order of their informational sensitivity: internal capital first, then debt and finally equity. More dynamic versions of the theory suggest that firms may choose to stockpile debt capacity, especially when growth prospects are high.

Finally, market timing (see, e.g., Baker and Wurgler 2002) posits that managers try to time the market based on their belief of the true firm value. That is, they will issue equity when they believe that the market overvalues their company. In this sense, a firm's capital structure is purely an outcome of its manager's past attempts to time the market.

This study examines the issuance decisions of 96 real estate investment trusts (REITs) between 1997 and 2006 to determine what role, if any, traditional capital structure theories play in REIT capital structure choice. During this period, our sample firms made 834 issuances of common equity, private debt, public debt and preferred equity. Following the methodology of Gomes and Phillips (2007), we use a multinomial logit model to estimate the determinants of the REIT security issuance decision.

REITs provide an interesting setting in which to examine capital structure because they have many structural features that rule out certain motivations for capital structure choices; indeed, because of these structural features it is not obvious how empirical results pertaining to non-REIT corporations can be extended to REITs. First, and most obviously, REITs are effectively tax exempt. ${ }^{2}$ This excludes taxbased motivations for issuing securities. ${ }^{3}$ Second, because REITs are required to pay out at least $90 \%$ of their taxable income as dividends, they are always issuing securities to fill the financing gap that arises from a lack of internal sources of capital. ${ }^{4}$ It also means that the free cash flow motivation for debt suggested by Jensen (1986) is unlikely to be overly important.

Third, REITs are a fairly transparent investment vehicle. That is, it is not apparent where the asymmetric information required for pecking-order theories to work is generated. For the most part

\footnotetext{
${ }^{2}$ REITs are required to pay out $90 \%$ of their taxable net income as dividends in order to maintain their REIT status. Furthermore, they are able to claim dividends paid as a deduction. Because REITs typically pay out at least $100 \%$ of their taxable net income, the dividends-paid deduction means that a REIT will, in general, have no tax payable. REITs with taxable REIT subsidiaries (TRS) do pay taxes through the TRS, because the TRS is taxable. The REIT cannot, however, shield the TRS's income at the REIT level. Only the TRS can shield its income using debt or interest deductions. See Boudry (2009) for a discussion of REIT dividend distribution and taxation.

${ }^{3}$ Howe and Shilling (1988) argue that, because REITs are not taxed at the corporate level, they would show a marked preference for not issuing debt due to competition in the debt market. Jaffe (1991) shows this not to be true and that a general irrelevance still holds.

${ }^{4}$ Ott, Riddiough and Yi (2005) show that REITs fund only 7\% of their investment through retained earnings; the corresponding figure for non-REIT firms is $70 \%$.
} 
REITs are in the cash yield business. They seek assets that provide a high yield from operations rather than returns through capital appreciation. The stable nature of this cash flow stream may limit the applicability of asymmetric information-based theories.

Fourth, REITs are one of the few industries where the firm's underlying assets trade in a secondary market. Because of this, analysts are effectively able to mark to market the firm's assets to calculate a net asset value (NAV) independent of the equity market. This means that REITs potentially face two costs of equity capital: one in the private market and another in the public market. Standard market timing would suggest that the firm is more likely to issue equity after large price increases, the logic being that this is when the firm's equity is most likely to be overvalued. Controlling for the price run-up, a price-to-NAV ratio greater than one suggests that the public market values the underlying property portfolio's cash flows more highly than the private market. A rational manager would be inclined to issue equity in the public market at such a time. Notice, however, that the manager is not trying to time the public equity market. The firm's equity need not be overvalued; all that is required is that capital be cheaper to issue in the public equity market. ${ }^{5}$

Finally, REITs are one of the few industries that issue preferred equity in any quantity. In fact, SDC Platinum's New Issues database reveals that companies in the REIT and utility industries together dominate preferred equity issuances. Preferred equity tends to be ignored as a source of financing in typical studies. From a theoretical perspective little guidance exists on the role it plays in the capital structure. In one of the few studies that address this issue, Heinkel and Zechner (1990) show that taxexempt firms may well be indifferent to issuing preferred equity.

Recently, Feng, Ghosh and Sirmans (2007) examine REIT capital structure decisions using the framework developed by Baker and Wurgler (2002). Their findings are quite different from Baker and Wurgler (2002), who find strong support for market timing. Feng, Ghosh and Sirmans (2007) find very little support for market timing and report results that are consistent with pecking-order theory. Like Feng, Ghosh and Sirmans (2007), this article addresses capital structure in REITs. However, the focus of our article is quite different from both Baker and Wurgler (2002) and Feng, Ghosh and Sirmans (2007). Both Baker and Wurgler (2002) and Feng, Ghosh and Sirmans (2007) are interested in explaining aggregate leverage or changes in aggregate leverage as a function of past market-to-book ratios. Our focus is on explaining marginal security choices. That is, we are interested in how firms choose to

\footnotetext{
${ }^{5}$ Damodaran and Liu (1993) find that insiders trade on the basis of NAVs and appraisals before they are publicly released.
} 
change their capital structure, not simply that they changed it. In fact, we find that the market-to-book ratio has very little role in explaining REIT security issuance decisions.

This study contains four main findings. First, we find strong support for market timing. Consistent with conventional market timing, firms are more likely to issue equity after they have had high past equity returns and when their price-to- NAV ratio is high. Second, the trade-off theory appears to play a small role in REIT security choice. The greater the difference between the weighted average interest rate the firm is paying on its debt and the rate on BBB debt, the more likely the firm is to issue all forms of equity over debt, with this being particularly true for preferred equity. Third, we find that, counter to the static pecking-order theory, asymmetric information appears to play a minimal role in security choice. This result differs from that of Feng, Ghosh and Sirmans (2007). Although our failure to find support for pecking-order theory may be a result of weak proxies for asymmetric information, the measures adopted are the same as those used in other studies that find support for the pecking-order theory, including Gomes and Phillips (2007). Furthermore, there is growing evidence (see, e.g., Bharath, Pasquariello and Wu 2009) to suggest that the pecking order does not hold in non-REIT firms where asymmetric information levels are likely to be low. Consistent with the finding for asymmetric information, we also find that firms that return capital to investors through excess dividends are two times more likely to raise equity capital than public debt-a clear violation of the pecking order.

Fourth, preferred equity issuances do not appear to be driven by the standard equity motivations. High price-to-NAV and past market returns do not increase the probability of issuing preferred equity. However, when the costs of issuing debt are high, REITs are more likely to issue preferred equity. The difference between the firm's weighted average interest rate and the BBB rate is a strong predictor of the firm's choice to issue preferred equity. Firms are, however, less likely to issue preferred equity when their overall leverage is high.

Overall, our findings suggest that the security issuances of REITs are heavily influenced by market timing behavior. REITs will issue securities when the relative cost of doing so is low, and they will avoid issuing securities when these costs appear high. In terms of traditional capital structure theories, REITs could best be described as supporting both forms of market timing.

The remainder of the article is organized as follows. The next section reviews the capital structure literature. The following sections describe the empirical methodology and our sample, respectively. Estimation results are reported in the penultimate section, and the final section contains our conclusions. 


\section{Literature Review}

Broadly speaking, the finance literature has simplified the capital structure literature into a horse race among three competing theories: (1) trade-off theory, (2) pecking-order theory and (3) market timing. Each of these theories has received considerable empirical attention with mixed results.

Trade-off theory posits that an optimal internal capital structure exists for a firm that weighs the benefits of debt against the bankruptcy costs of debt. For REITs the trade-off is not obvious because of the effectively tax-exempt status of REITs at the corporate level. Howe and Shilling (1988) argue that this lack of tax deductibility would force REITs to have a $100 \%$ equity capital structure. The logic behind this argument is that, if REITs have to compete for debt funds against non-REIT firms that receive the tax benefit of debt, they will be at a competitive disadvantage and will find it too expensive to issue debt. Jaffe (1991), however, shows that this is not the case and, using a proof similar to the original Modigliani and Miller (1958) irrelevance proposition, shows that capital structure irrelevance does indeed hold, at least theoretically, for REITs.

Myers (1984) and Myers and Majluf (1984) argue that a pecking order of securities exists for a firm and that firms will issue securities in order of their information sensitivity. Critical to pecking-order models is the presence of asymmetric information between managers and the market. Han (2006) argues that these information asymmetries are likely to be severe for REITs because monitoring a REIT involves local knowledge of the real estate market. Downs and Gunner (1999) examine microstructure data for the last quarter of 1995 and provide evidence that asymmetric information plays a role in REIT pricing. Given the considerable change in market structure since then, especially in terms of institutional ownership, it is uncertain how this result pertains to our sample. Garmaise and Moskowitz (2004) also show that asymmetric information plays a critical role in commercial property transactions. Their sample, however, relates to small commercial properties; in fact, of the 10,351 transactions in their sample, only 42 were made by REITs.

More recently, market timing has been highlighted as a potential explanation for security issuances. Graham and Harvey (2001) report that, in a survey of chief financial officers, two-thirds said the value of their stock was an important determinant of their choice to issue equity. Baker and Wurgler (2002) test the market timing hypothesis for a large cross-section of firms and find strong support for it. They show that there is a strong negative relationship between the external finance weighted marketto-book ratio and current leverage. In the REIT literature, Feng, Ghosh and Sirmans (2007) replicate the Baker and Wurgler (2002) study using REIT data and find little support for market timing. Their results 
are in fact the exact opposite: high past levels of the market-to-book ratio predict higher current leverage. They also find similar results when they use a smaller subsample of firms for which they can obtain NAV estimates from Green Street. Overall, they find greatest support for the pecking order in their REIT sample. ${ }^{6}$

In addition to the market timing argument as in Baker and Wurgler (2002), the fact that real estate trades in both the private market and the public market adds a new wrinkle. A REIT's stock price summarizes how the public equity market values its cash flows, whereas its NAV summarizes how the private market values these same cash flows. ${ }^{7}$ Controlling for past returns and growth expectations, the price-to-NAV ratio can be interpreted as a relative cost of equity capital. As it is not trivial to arbitrage public and private markets, persistent premiums or discounts to NAV can rationally occur. One would naturally expect managers to issue equity in the public market when the cost of equity in that market is low, that is, issue equity when stock price is high relative to NAV. The mechanism driving this, however, need not be the same as the standard market timing argument. In our case, the manager is not strictly trying to take advantage of overpricing in the equity market; she or he is merely issuing equity into a market that places a higher value on those cash flows.

\section{Methodology}

The approach that we adopt to test the competing capital structure theories is to examine issuance decisions. This differs from the standard methodology, which typically examines leverage ratios through time as in, for example, Lemmon and Zender (2004) and Frank and Goyal (2003). A noticeable example of the approach that we employ is Gomes and Phillips (2007), who examine the security issuance decisions of a broad cross-section of firms with a particular emphasis on why firms chose public or private securities.

To examine the factors affecting a firm's choice of security issuance we estimate a multinomial logit model with four choices: (1) common equity, (2) preferred equity, (3) public debt and (4) private debt. In this framework the security choices are the dependent variables, and the independent variables are motivated by the competing capital structure theories.

\footnotetext{
${ }^{6}$ For non-REIT firms, Shyam-Sunder and Myers (1999), Lemmon and Zender (2004), and Gomes and Phillips (2007) find the pecking order is a reasonable approximation of firm capital structure choices, while Fama and French (2002) and Frank and Goyal (2003) find the opposite.

${ }^{7}$ Note that, because REITs can be viewed as financial intermediaries, they provide value beyond their holdings of tangible assets.
} 
Theoretically it is possible to decompose the outcomes (common equity, preferred equity, public debt and private debt) into even finer outcomes. The reason we adopt our categorization is fourfold. First, within outcomes the securities tend to be fairly homogenous. For example, the preferred equity group is virtually all redeemable but not convertible, whereas the public debt is predominantly senior unsecured debt. Second, from an economic perspective, we hope that keeping the partitioning at this coarser level will result in the menu of securities being restricted to those that an average firm would consider issuing. Third, the finer the menu of securities, the more likely it becomes that the securities will be close substitutes for one another. ${ }^{8}$ By keeping the categorization at the current level, we maintain a security menu in which each security has characteristics that are significantly different from the other securities. Finally, data restrictions make it awkward to use a finer partitioning: for example, there are not enough private issues of equity or preferred in our sample to employ our statistical approaches separately for those outcomes.

\section{Data and Sample}

\section{Issuing Firms and Issue Characteristics}

The main constraint imposed on the data comes from the availability of analyst data. This requirement biases our sample toward larger REITs, because brokerages are more likely to provide coverage for larger firms. ${ }^{9}$

Unlike funds from operations (FFO) or similar measures, NAV data are not readily available in standard analyst databases such as IBES. We obtain NAV data from SNL Securities and from Investext. SNL contains a fairly comprehensive set of analyst NAVs for a broad cross-section of both REITs and brokerages. However, this data set dates back only to the start of 2001. We use hand-collected analyst reports from Investext to obtain NAV estimates prior to this and to fill gaps in SNL's coverage. ${ }^{10}$ Although the coverage universe for both SNL and Investext is not complete, both contain reports from the major brokerages. Furthermore, because we are considering consensus numbers rather than an

\footnotetext{
${ }^{8}$ The critical assumption behind the multinomial logit model is the irrelevance of independent alternatives (IIA), which requires that the choices not be close substitutes for one another. In our estimation we fail to reject the IIA assumption using the Hausman and McFadden (1984) test.

${ }^{9}$ This bias away from micro-REITs is a potential explanation for finding a lack of support for the pecking order based on measures of asymmetric information, because it is these small firms among which problems of asymmetric information are likely to be greatest.

${ }^{10}$ Investext has been used as a source of data in other studies. See, for example, Mikhail, Asquith and Au (2005).
} 
individual analyst's opinion, the incomplete nature of the data source is unlikely to bias the results of the study. ${ }^{11}$

Survivorship bias does not play a role in our sample. We include both active and dead (e.g., acquired, converted, etc.) firms in our sample. Our only restriction is that the firm must have been a public REIT when it was making the issuance. There is some overlap in our issuances data. This typically occurs in public debt deals where the issuance is effectively tranched and we observe multiple issuances by a firm in a short period (typically less than a week). For other security types, simultaneous issuances are not prevalent. The reported results are based on an estimation in which we combine these tranched issuances into a single issuance, but our results are similar if we consider them as individual issuances.

Security issuance data are collected from three sources: (1) National Association of Real Estate Investment Trusts (NAREIT), (2) SNL Securities and (3) Loan Pricing Corporation's Deal Scan database. NAREIT and SNL Securities provide capital-offering data for publicly traded REITs. Both databases are fairly comprehensive in their coverage and provide information on common and preferred equity issuances and public and private debt issuances. ${ }^{12}$ Neither NAREIT nor SNL provide information on syndicated loans, so we collect syndicated loan data from Deal Scan. ${ }^{13}$ In combination, these three databases give a broad coverage of the major security issuances for our sample firms.

As this study examines the choice between different security types, it is interesting to examine how many firms issued multiple types of securities during the sample. Panel A of Table 1 reports the number of firms issuing a given security during the sample period, whereas Panel $B$ reports the number of firms that issued one, two, three or all four types of securities during the sample period. Of the 96 firms in the sample, 77 issued common equity, 61 issued preferred equity, 39 issued public debt and 57 issued private debt. In terms of the number of different types of securities issued by a given firm, 18 firms issued only one class of security, 34 issued two classes, 28 issued three classes and 16 firms issued all four classes of securities.

\footnotetext{
${ }^{11}$ Green Street Advisors is another potential source of NAV data, but an examination of the coverage provided by Green Street suggests we have a more comprehensive coverage. Gentry and Mayer (2002), for example, have a sample of 70 firms using Green Street data, while Feng, Ghosh and Sirmans (2007) have 60 in any given year. ${ }^{12}$ An examination of SDC Platinum's New Issues database shows that combining NAREIT and SNL provides better coverage than SDC.

${ }^{13}$ We exclude revolving credit lines from our analysis because an examination of filing prospectuses indicates that, in general, credit lines are used for short-term financing with these loans later being replaced by long-term financing.
} 
Table 1 a Firm and issue characteristics.

\begin{tabular}{lll}
\hline \hline Panel A: Issues & & \\
\hline Security Type & Number of Issues & Number of Issuing Firms \\
\hline Common Equity & 210 & 77 \\
Preferred Equity & 191 & 61 \\
Public Debt & 283 & 39 \\
Private Debt & 150 & 57 \\
Total & 834 & \\
\hline Panel B: Number of Security Types Issued & \\
\hline Security Types & & Number of Firms \\
\hline 1 & & 18 \\
2 & & 34 \\
3 & & 28 \\
4 & & 16 \\
Total & 96 \\
\hline
\end{tabular}

Notes: This table reports descriptive statistics for issuances by 96 equity REITs between 1997 and 2006. Panel A reports the number of issues and the number of firms issuing a given type of security. Panel B reports the number of firms that issued a one, two, three or all four security types from Panel A during the sample period.

Table 2 reports issuance characteristics by issue type and year. Two characteristics are noticeable in the data. First, there does appear to be significant variation through time in the number of issues coming to market. This is particularly apparent for common equity issuances. Especially noticeable is the marked decline in equity issuances in the late 1990s, which corresponded to a REIT bear market.

The second characteristic noticeable in the data is that the size of issuances are of similar economic orders of magnitude. The average issue size is approximately $\$ 135$ million for common equity; preferred equity is smaller at $\$ 84$ million; public debt averages $\$ 142$ million; and private debt has the largest average issue size at $\$ 287$ million. Differences-in-means tests reveal that private debt is significantly larger than all other issue types, whereas preferred equity is smaller than all other issue types. The null hypothesis of equal size could not be rejected for common equity and public debt. 
Table 2 a Issue characteristics.

\begin{tabular}{|c|c|c|c|c|c|c|c|c|c|c|}
\hline \multicolumn{11}{|c|}{ Panel A: Equity Issues } \\
\hline \multirow[b]{2}{*}{ Year } & \multicolumn{5}{|c|}{ Common Equity } & \multicolumn{5}{|c|}{ Preferred Equity } \\
\hline & Issues & Mean & SD & Min. & Max. & Issues & Mean & SD & Min. & Max. \\
\hline 1997 & 6 & 187.26 & 207.99 & 10.27 & 517.6 & 4 & 125 & 54.01 & 50 & 175 \\
\hline 1998 & 16 & 31.93 & 27.44 & 3 & 90.4 & 10 & 86.5 & 64.59 & 20 & 250 \\
\hline 1999 & 4 & 85.41 & 71.73 & 3.94 & 150 & 11 & 51.73 & 31.85 & 11.02 & 100 \\
\hline 2000 & 2 & 366.62 & 426.73 & 64.88 & 668.36 & 10 & 61.61 & 83.21 & 1 & 250 \\
\hline 2001 & 19 & 100.91 & 103.46 & 2.69 & 396.67 & 14 & 87.34 & 133.2 & 10 & 510 \\
\hline 2002 & 18 & 79.89 & 87.1 & 8.7 & 323.46 & 21 & 65.68 & 60.38 & 5 & 212.5 \\
\hline 2003 & 44 & 86.78 & 90.21 & 12 & 605.51 & 42 & 81.28 & 50.21 & 2.52 & 205 \\
\hline 2004 & 37 & 179.8 & 283.3 & 3.14 & 1550.65 & 39 & 83.53 & 56.98 & 0.13 & 250 \\
\hline 2005 & 27 & 134.15 & 167.94 & 8.3 & 780.75 & 24 & 91.7 & 70.14 & 6 & 250 \\
\hline 2006 & 37 & 221.04 & 232.59 & 12.4 & 1012.5 & 16 & 127.45 & 125.82 & 10 & 517.5 \\
\hline \multicolumn{2}{|c|}{ Total 210} & 134.93 & 189.4 & 2.69 & 1550.65 & 191 & 84.1 & 74.77 & 0.13 & 517.5 \\
\hline \multicolumn{11}{|c|}{ Panel B: Debt Issues } \\
\hline & \multicolumn{5}{|c|}{ Public Debt } & \multicolumn{5}{|c|}{ Private Debt } \\
\hline 1997 & 3 & 57.77 & 78.82 & 6.2 & 148.5 & 3 & 175 & 43.3 & 125 & 200 \\
\hline 1998 & 9 & 107.06 & 96.56 & 5.5 & 318 & 7 & 181.13 & 102.4 & 50 & 328 \\
\hline 1999 & 23 & 124.15 & 95.46 & 5 & 299.8 & 13 & 118.03 & 105.38 & 10 & 420 \\
\hline 2000 & 21 & 134.57 & 138.75 & 10 & 500 & 16 & 150.16 & 125.83 & 10 & 475 \\
\hline 2001 & 20 & 170 & 172.66 & 10 & 750 & 14 & 148.15 & 133.55 & 14.5 & 494 \\
\hline 2002 & 34 & 132.09 & 128.81 & 5 & 500 & 18 & 156.71 & 184.68 & 9 & 750 \\
\hline 2003 & 30 & 130.2 & 121.71 & 6 & 500 & 17 & 206.76 & 124.12 & 20 & 450 \\
\hline 2004 & 58 & 134.42 & 146.03 & 0.21 & 800 & 28 & 186.32 & 125.68 & 34.5 & 555 \\
\hline 2005 & 54 & 110.51 & 120.77 & 0.13 & 500 & 22 & 726.78 & 945.83 & 69.8 & 3650 \\
\hline 2006 & 31 & 256.45 & 147.69 & 25 & 650 & 12 & 648.13 & 829.29 & 37.5 & 2850 \\
\hline \multicolumn{2}{|c|}{ Total 283} & 142.51 & 138.2 & 0.13 & 800 & 150 & 287.49 & 490.51 & 9 & 3650 \\
\hline \multicolumn{11}{|c|}{$\begin{array}{l}\text { Notes: This table reports descriptive statistics for issuances by } 96 \text { equity REITs from } \\
1997 \text { to } 2006 \text {. Panel A reports common equity and preferred equity issuances. Panel B } \\
\text { reports public debt and private debt issuances. All values are in millions except number } \\
\text { of issues. }\end{array}$} \\
\hline
\end{tabular}

\section{Market Timing Measures}

To measure market timing we include the price-to-NAV ratio along with the firm's average monthly return (computed from CRSP data) over the 12 months prior to the issuance. The price-to-NAV ratio is constructed as follows. In the 180-day window prior to the issuance, for each analyst we collect price-to- NAV estimates. We then average across analysts to get a consensus number for that firm. Within the 180-day window, if an analyst has multiple price-to- NAV forecasts, we average across them before calculating the consensus number across analysts. Our results are not changed if instead of averaging the analyst's forecasts, we take the analyst's most recent forecast and use it in calculating the consensus number. Using a 90-day window also has no effect on our estimation. 
Standard market timing would suggest a positive relationship between average returns and equity issuances. Controlling for the average return, issuing equity when the price-to-NAV ratio is high suggests that the REIT is trying to time the public versus private real estate market.

Table 3 reports the price-to-NAV ratio and average monthly return for issuing firms during each year of the sample. There is a good deal of time-series and cross-sectional variation in price-to-NAV ratios. On average, the sample firms trade at a $6 \%$ premium to NAV, but for individual firms the ratio ranged from as low as a $61 \%$ discount to as high as a $64 \%$ premium. Although these may appear extreme, hand-collected analyst reports show that they are not due to a single analyst making an extreme estimate or a calculation error due to stock splits; in both examples, numerous analysts were making similar estimates for each company.

One potential wedge between a firm's price and NAV is caused by the firm's managerial skill, that is, the market values the manager's ability to grow cash flows over the static real estate portfolio. As we control expected growth, a myopic NAV should be reflected in our growth proxy. Nonetheless, although managerial skill may explain some of the average premium to NAV, it does not explain why premiums and discounts are correlated across firms. Firms tend to trade at premiums and discounts together. Under the managerial story, this implies that management skill is not only time varying, but that the skill of most managers varies in the same way.

Table 3 a Measures of market timing.

\begin{tabular}{|c|c|c|c|c|c|c|c|c|c|}
\hline \multirow[b]{2}{*}{ Year } & \multicolumn{5}{|c|}{ Price-to-NAV Ratio } & \multicolumn{4}{|c|}{ Average Monthly Return } \\
\hline & Issues & Mean & SD & Min. & Max. & Mean & SD & Min. & Max. \\
\hline 1997 & & 1.15 & 0.12 & 0.97 & 1.43 & 2.66 & 0.93 & 1.26 & 4.58 \\
\hline 1998 & 42 & 1.14 & 0.16 & 0.92 & 1.46 & 1.04 & 1.38 & -2.73 & 3.43 \\
\hline 1999 & 51 & 0.92 & 0.1 & 0.71 & 1.17 & -0.14 & 1.23 & -2.52 & 2.68 \\
\hline 2000 & 49 & 0.89 & 0.11 & 0.62 & 1.16 & 1.15 & 1.6 & -4.77 & 4.06 \\
\hline 2001 & 67 & 0.93 & 0.11 & 0.39 & 1.16 & 2.2 & 1.05 & -0.66 & 4.41 \\
\hline 2002 & 91 & 1 & 0.11 & 0.73 & 1.39 & 1.72 & 1.15 & -0.84 & 4.37 \\
\hline 2003 & 133 & 1.1 & 0.13 & 0.8 & 1.64 & 1.72 & 1.04 & -1.24 & 4.65 \\
\hline 2004 & 162 & 1.14 & 0.12 & 0.93 & 1.63 & 2.46 & 1.08 & -0.01 & 5.43 \\
\hline 2005 & 127 & 1.1 & 0.1 & 0.84 & 1.38 & 1.88 & 1 & -0.82 & 4.01 \\
\hline 2006 & 96 & 1.08 & 0.09 & 0.83 & 1.33 & 2.1 & 1.17 & -0.68 & 5.29 \\
\hline Total & 834 & 1.06 & 0.14 & 0.39 & 1.64 & 1.81 & 1.3 & -4.77 & 5.43 \\
\hline
\end{tabular}

Notes: This table reports descriptive statistics for price-to-NAV ratio and average monthly return for 96 equity REITs making security issuances from 1997 to 2006. Price-to-NAV is the consensus price-to-NAV ratio constructed during a 180-day window prior to the issuance. Average monthly return is calculated over the year prior to the issuance. Returns are in percentages.

Consistent with our private equity versus public equity argument, the price-to- NAV ratio trends through time, with firms trading on average at discounts in the late 1990s and early 2000s and at 
premiums during other periods. These periods of discounts coincide with periods when REITs appeared anecdotally to be out of favor with the public equity market.

Table 4 Ш Price-to-NAV ratio by issue type.

\begin{tabular}{|c|c|c|c|c|c|c|c|c|c|c|}
\hline \multicolumn{11}{|c|}{ Panel A: Equity Issues } \\
\hline \multirow[b]{2}{*}{ Year } & \multicolumn{5}{|c|}{ Common Equity } & \multicolumn{5}{|c|}{ Preferred Equity } \\
\hline & Issues & Mean & SD & Min. & Max. & Issues & Mean & SD & Min. & Max. \\
\hline 1997 & 6 & 1.21 & 0.17 & 0.97 & 1.43 & 4 & 1.12 & 0.09 & 1.01 & 1.22 \\
\hline 1998 & 16 & 1.18 & 0.14 & 0.97 & 1.44 & 10 & 1.19 & 0.18 & 0.92 & 1.46 \\
\hline 1999 & 4 & 0.92 & 0.14 & 0.74 & 1.06 & 11 & 0.94 & 0.09 & 0.8 & 1.09 \\
\hline 2000 & 2 & 0.93 & 0 & 0.92 & 0.93 & 10 & 0.89 & 0.07 & 0.77 & 0.99 \\
\hline 2001 & 19 & 0.99 & 0.1 & 0.83 & 1.16 & 14 & 0.93 & 0.11 & 0.64 & 1.08 \\
\hline 2002 & 18 & 1.02 & 0.07 & 0.94 & 1.13 & 21 & 0.97 & 0.08 & 0.8 & 1.11 \\
\hline 2003 & 44 & 1.11 & 0.11 & 0.91 & 1.28 & 42 & 1.12 & 0.14 & 0.8 & 1.59 \\
\hline 2004 & 37 & 1.16 & 0.1 & 0.97 & 1.36 & 39 & 1.16 & 0.13 & 0.94 & 1.63 \\
\hline 2005 & 27 & 1.12 & 0.13 & 0.84 & 1.38 & 24 & 1.11 & 0.11 & 0.93 & 1.29 \\
\hline 2006 & 37 & 1.09 & 0.09 & 0.92 & 1.33 & 16 & 1.06 & 0.1 & 0.86 & 1.18 \\
\hline Total & 210 & 1.1 & 0.12 & 0.74 & 1.44 & 191 & 1.07 & 0.15 & 0.64 & 1.63 \\
\hline
\end{tabular}

Panel B: Debt Issues

\begin{tabular}{|c|c|c|c|c|c|c|c|c|c|c|}
\hline \multirow[b]{2}{*}{1997} & \multicolumn{5}{|c|}{ Public Debt } & \multicolumn{5}{|c|}{ Private Debt } \\
\hline & 3 & 1.09 & 0.03 & 1.07 & 1.12 & 3 & 1.13 & 0.07 & 1.07 & 1.21 \\
\hline 1998 & 9 & 1.1 & 0.18 & 0.92 & 1.4 & 7 & 1.04 & 0.09 & 0.95 & 1.18 \\
\hline 1999 & 23 & 0.94 & 0.11 & 0.79 & 1.17 & 13 & 0.87 & 0.09 & 0.71 & 0.99 \\
\hline 2000 & 21 & 0.93 & 0.12 & 0.7 & 1.1 & 16 & 0.84 & 0.11 & 0.62 & 1.01 \\
\hline 2001 & 20 & 0.92 & 0.05 & 0.79 & 0.99 & 14 & 0.86 & 0.15 & 0.39 & 0.99 \\
\hline 2002 & 34 & 1.04 & 0.11 & 0.88 & 1.39 & 18 & 0.92 & 0.1 & 0.73 & 1.1 \\
\hline 2003 & 30 & 1.11 & 0.16 & 0.82 & 1.64 & 17 & 1.04 & 0.15 & 0.8 & 1.24 \\
\hline 2004 & 58 & 1.14 & 0.11 & 0.94 & 1.6 & 28 & 1.11 & 0.13 & 0.93 & 1.42 \\
\hline 2005 & 54 & 1.09 & 0.08 & 0.93 & 1.32 & 22 & 1.11 & 0.09 & 0.87 & 1.27 \\
\hline 2006 & 31 & 1.06 & 0.07 & 0.89 & 1.18 & 12 & 1.07 & 0.1 & 0.83 & 1.18 \\
\hline Total & 283 & 1.06 & 0.13 & 0.7 & 1.64 & 150 & 1 & 0.16 & 0.39 & 1.42 \\
\hline
\end{tabular}

Notes: This table reports price-to-NAV ratios for 96 equity REITs making security issuances between 1997 and 2006. Panel A reports price-to-NAV ratios by year for common equity and preferred equity issuances. Panel B reports price-to-NAV ratios by year for public debt and private debt issuances.

Average monthly return also varies considerably through time, with the mean return being 1.81\%. REITs experienced low average returns during the 1998- 2000 period, which is consistent with price-to-NAV ratios. The correlation between the average monthly return and the price-to-NAV ratio is 0.42 , suggesting that they are capturing similar but not identical effects.

Table 4 reports the price-to-NAV ratio by issue type. A simple market timing argument suggests that the price-to-NAV ratio should be highest for those firms issuing equity. A comparison of the total averages between Panels $A$ and $B$ shows this to be the case. The price-to-NAV ratio for common equity issuances average 1.1; for preferred equity they average 1.07; for public debt issuances they average 
1.06; and for private debt they average 1.00. Formal $t$ tests of differences in means shows that common equity has a price-to-NAV ratio significantly higher than all other security types on average, whereas private debt has a significantly lower price-to-NAV ratio than all other security types.

Preferred equity and public debt are not, on average, significantly different from each other.

These averages suggest that there may be some merit to the market timing argument, at least in terms of price-to-NAV ratios.

Table 5 reports average monthly return by issue type and issue year. On average, the mean return for common equity issues is $2.29 \%$; the return for preferred equity is $1.91 \%$; public debt issues have an average return of $1.45 \%$; and private debt issues have an average return of $1.69 \%$. Difference of means tests show that average returns of common equity issuers are higher than all other issue type, whereas average returns of private debt issuers are lower than all other issue type, and preferred equity issuers have higher average returns than public debt issuers. These results are similar to those for the price-to-NAV ratio.

Table 5 Mean return by issue type.

\begin{tabular}{|c|c|c|c|c|c|c|c|c|c|c|}
\hline \multicolumn{11}{|c|}{ Panel A: Equity Issues } \\
\hline \multirow[b]{2}{*}{ Year } & \multicolumn{5}{|c|}{ Common Equity } & \multicolumn{5}{|c|}{ Preferred Equity } \\
\hline & Issues & Mean & SD & Min. & Max. & Issues & Mean & SD & Min. & Max. \\
\hline 1997 & 6 & 3.16 & 1.16 & 1.96 & 4.58 & 4 & 2.11 & 0.68 & 1.26 & 2.72 \\
\hline 1998 & 16 & 1.44 & 0.68 & 0.43 & 2.72 & 10 & 1.52 & 1.52 & -1.58 & 3.43 \\
\hline 1999 & 4 & -0.38 & 2.11 & -2.52 & 1.57 & 11 & 0.39 & 0.91 & -0.72 & 1.63 \\
\hline 2000 & 2 & 3.29 & 0.26 & 3.11 & 3.48 & 10 & 1.2 & 1.39 & -0.25 & 4.06 \\
\hline 2001 & 19 & 2.39 & 1.28 & -0.66 & 4.41 & 14 & 1.84 & 1.01 & 0.2 & 3.37 \\
\hline 2002 & 18 & 2.75 & 0.69 & 2 & 4.37 & 21 & 1.6 & 1.18 & -0.7 & 3.43 \\
\hline 2003 & 44 & 1.81 & 0.8 & -1.04 & 3.54 & 42 & 1.88 & 1.31 & -1.24 & 4.65 \\
\hline 2004 & 37 & 3.03 & 0.93 & 1.18 & 5.43 & 39 & 2.57 & 1.05 & -0.01 & 4.63 \\
\hline 2005 & 27 & 2.17 & 0.96 & 0.4 & 4.01 & 24 & 2.09 & 1.12 & -0.7 & 4.01 \\
\hline 2006 & 37 & 2.37 & 1.27 & 0.39 & 5.29 & 16 & 2.23 & 1.26 & -0.13 & 4.62 \\
\hline Total & 210 & 2.29 & 1.17 & -2.52 & 5.43 & 191 & 1.91 & 1.27 & -1.58 & 4.65 \\
\hline \multicolumn{11}{|c|}{ Panel B: Debt Issues } \\
\hline & \multicolumn{5}{|c|}{ Public Debt } & \multicolumn{5}{|c|}{ Private Debt } \\
\hline 1997 & 3 & 2.53 & 0.29 & 2.31 & 2.86 & 3 & 2.5 & 0.95 & 1.65 & 3.54 \\
\hline 1998 & 9 & 0.54 & 1.54 & -1.56 & 2.75 & 7 & 0.11 & 1.72 & -2.73 & 2.88 \\
\hline 1999 & 23 & -0.67 & 1.07 & -2.29 & 1.6 & 13 & 0.42 & 1.13 & -1.51 & 2.68 \\
\hline 2000 & 21 & 1.25 & 1.9 & -4.77 & 4.05 & 16 & 0.71 & 1.19 & -1.07 & 3.47 \\
\hline 2001 & 20 & 2.33 & 0.94 & 0.73 & 3.98 & 14 & 2.1 & 0.9 & 0.13 & 3.87 \\
\hline 2002 & 34 & 1.39 & 0.99 & -0.52 & 3.22 & 18 & 1.47 & 1.25 & -0.84 & 2.88 \\
\hline 2003 & 30 & 1.42 & 0.94 & -0.77 & 3.57 & 17 & 1.64 & 1.02 & -0.17 & 3.21 \\
\hline 2004 & 58 & 1.89 & 0.96 & 0.44 & 4.18 & 28 & 2.76 & 1 & 0.26 & 4.94 \\
\hline 2005 & 54 & 1.61 & 0.87 & -0.82 & 3.31 & 22 & 1.94 & 1.1 & 0.01 & 3.98 \\
\hline 2006 & 31 & 1.75 & 1.01 & -0.68 & 3.3 & 12 & 2 & 1.03 & 0.51 & 4.62 \\
\hline Total & 283 & 1.45 & 1.28 & -4.77 & 4.18 & 150 & 1.69 & 1.34 & -2.73 & 4.94 \\
\hline \multicolumn{11}{|c|}{$\begin{array}{l}\text { Notes: This table reports average monthly returns for } 96 \text { equity REITs issuing securities } \\
\text { between } 1997 \text { and } 2006 \text {. Panel A reports mean returns by year for common equity and } \\
\text { preferred equity issuances. Panel B reports mean return by year for public debt and } \\
\text { private debt issuances. }\end{array}$} \\
\hline
\end{tabular}




\section{Pecking Order Measures}

The accounting literature has long viewed measures of accuracy and dispersion among analysis estimates as measures of asymmetric information. Lang and Lundholm (1996) show that accuracy increases and dispersion decreases when firms disclose more information about future earnings. Following Gomes and Phillips (2007) we employ "forecast surprise," defined as the absolute difference between the mean quarterly analyst FFO forecast and the actual quarterly FFO value, all divided by the current stock price, as a measure of asymmetric information. ${ }^{14}$ The forecast surprise ratio is calculated for the quarter before the issuance with FFO data from IBES, with a greater surprise suggesting greater asymmetric information. ${ }^{15}$

Table 6 reports the average forecast surprise for each security type across years. The average surprise is $0.09 \%$ for common equity, $0.10 \%$ for preferred equity, $0.11 \%$ for public debt and $0.15 \%$ for private debt. $t$ tests of differences in means are unable to reject the null hypothesis for any combination of pairs. The level of the surprise is significantly smaller than that reported by Gomes and Phillips (2007).

Recent papers such as Fisher, Heinkel and Zender (1989) and Ju et al. (2002) have developed models of a dynamic pecking order. These theories suggest that firms will stockpile their debt capacity when growth prospects are good. To capture this we include the consensus analyst long-term growth rate of the firm in the 180 days prior to the issuance. Growth rates were obtained from IBES and were supplemented by hand-collected reports from Investext. ${ }^{16}$

One of the obvious conclusions of the pecking order (see Fama and French 2002) is that firms should not pay dividends or issue equity. If equity is costly to issue, then the firm would be better off retaining cash than paying it out in dividends and then having to issue more equity. As REITs are required to pay out at least $90 \%$ of their taxable net income in dividends, the retention of dividends is not an option. However, if the pecking order still holds, we would expect REITs to retain capital where possible. Because of this, we include a dummy variable equal to one if the REIT had a nonzero return of capital component in the prior year's dividend. For tax purposes a REIT decomposes its dividend into ordinary income, capital gains and return of capital components. A dividend is deemed a return of capital if the REIT pays out greater than $100 \%$ of its taxable income or returns the tax basis from

\footnotetext{
${ }^{14}$ FFO is the standard earnings measure reported in the REIT industry. It essentially adds back noncash items such as depreciation and amortization to earnings.

${ }^{15}$ As a robustness check, we ran the analysis with forecast dispersion, calculated as the standard deviation of analyst quarterly FFO forecasts divided by the current stock price. Results were similar to those reported.

${ }^{16}$ Compared to FFO forecasts, IBES' coverage of long-term growth rates is less comprehensive.
} 
property sales. Tax information was obtained from NAREIT and supplemented with data from annual reports and each REIT's investor information Web pages.

Table 6 Forecast surprise by issue type.

\begin{tabular}{|c|c|c|c|c|c|c|c|c|c|c|}
\hline \multicolumn{11}{|c|}{ Panel A: Equity Issues } \\
\hline \multirow[b]{2}{*}{ Year } & \multicolumn{5}{|c|}{ Common Equity } & \multicolumn{5}{|c|}{ Preferred Equity } \\
\hline & Issues & Mean & SD & Min. & Max. & Issues & Mean & $\mathrm{SD}$ & Min. & Max. \\
\hline 1997 & 6 & 0.058 & 0.077 & 0.000 & 0.208 & 4 & 0.045 & 0.037 & 0.000 & 0.082 \\
\hline 1998 & 16 & 0.073 & 0.077 & 0.000 & 0.306 & 10 & 0.103 & 0.095 & 0.000 & 0.251 \\
\hline 1999 & 4 & 0.056 & 0.037 & 0.023 & 0.106 & 11 & 0.024 & 0.024 & 0.000 & 0.066 \\
\hline 2000 & 2 & 0.049 & 0.053 & 0.011 & 0.086 & 10 & 0.052 & 0.063 & 0.012 & 0.225 \\
\hline 2001 & 19 & 0.024 & 0.024 & 0.000 & 0.07 & 14 & 0.054 & 0.051 & 0.000 & 0.136 \\
\hline 2002 & 18 & 0.037 & 0.030 & 0.000 & 0.095 & 21 & 0.065 & 0.115 & 0.000 & 0.461 \\
\hline 2003 & 44 & 0.113 & 0.137 & 0.000 & 0.531 & 42 & 0.119 & 0.190 & 0.000 & 0.992 \\
\hline 2004 & 37 & 0.134 & 0.125 & 0.000 & 0.55 & 39 & 0.114 & 0.121 & 0.000 & 0.613 \\
\hline 2005 & 27 & 0.107 & 0.081 & 0.000 & 0.263 & 24 & 0.169 & 0.173 & 0.013 & 0.637 \\
\hline 2006 & 37 & 0.086 & 0.106 & 0.000 & 0.472 & 16 & 0.100 & 0.092 & 0.000 & 0.366 \\
\hline Total & 210 & 0.090 & 0.106 & 0.000 & 0.556 & 191 & 0.101 & 0.137 & 0.000 & 0.992 \\
\hline \multicolumn{11}{|c|}{ Panel B: Debt Issues } \\
\hline & \multicolumn{5}{|c|}{ Public Debt } & \multicolumn{5}{|c|}{ Private Debt } \\
\hline 1997 & 3 & 0.011 & 0.018 & 0.000 & 0.032 & 3 & 0.029 & 0.026 & 0.012 & 0.059 \\
\hline 1998 & 9 & 0.042 & 0.031 & 0.000 & 0.111 & 7 & 0.095 & 0.090 & 0.000 & 0.251 \\
\hline 1999 & 23 & 0.043 & 0.041 & 0.000 & 0.147 & 13 & 0.038 & 0.029 & 0.000 & 0.094 \\
\hline 2000 & 21 & 0.056 & 0.056 & 0.000 & 0.188 & 16 & 0.054 & 0.065 & 0.000 & 0.209 \\
\hline 2001 & 20 & 0.031 & 0.038 & 0.000 & 0.118 & 14 & 0.335 & 1.091 & 0.000 & 4.123 \\
\hline 2002 & 34 & 0.042 & 0.036 & 0.000 & 0.136 & 18 & 0.142 & 0.299 & 0.000 & 1.231 \\
\hline 2003 & 30 & 0.052 & 0.055 & 0.000 & 0.259 & 17 & 0.061 & 0.048 & 0.000 & 0.146 \\
\hline 2004 & 58 & 0.160 & 0.302 & 0.000 & 1.288 & 28 & 0.314 & 0.845 & 0.000 & 4.284 \\
\hline 2005 & 54 & 0.261 & 0.465 & 0.000 & 1.677 & 22 & 0.116 & 0.120 & 0.000 & 0.469 \\
\hline 2006 & 31 & 0.069 & 0.061 & 0.000 & 0.237 & 12 & 0.082 & 0.067 & 0.010 & 0.205 \\
\hline Total & 283 & 0.112 & 0.260 & 0.000 & 1.677 & 150 & 0.151 & 0.509 & 0.000 & 4.284 \\
\hline
\end{tabular}

Notes: This table reports descriptive statistics by issue type for forecast surprise. The forecast surprise is the absolute difference between quarterly funds from operations (FFO) and analyst consensus FFO divided by the current share price. Panel A reports results for common equity issuances and preferred equity issuances, whereas Panel B reports results for public debt issuances and private debt issuances. All values reported are percentages.

\section{Tradeoff Theory}

Tradeoff theory predicts that any variable measuring the expected costs of bankruptcy should have a negative relationship with debt issuance and a positive relationship with equity issuance. To reflect this we include the firm's market leverage in the prior quarter, calculated as the book value of debt and preferred stock divided by the market value of the firm (book value of debt and preferred equity plus the market value of equity). All else equal, firms with higher leverage should be less likely to issue debt.

Second, we include the spread between the yield on long-term BBB debt and the 10-year treasury. When this default spread is high, default risk in the economy is greater, suggesting that 
expected bankruptcy costs are higher. Thus, firms would be less likely to issue debt when the default spread is high.

Third, we complement the default spread with the spread between the firm's weighted average interest rate as reported by SNL and the rate on 10-year BBB debt. Although the default spread measures risk at the economy level, the interest rate difference measures it at the firm level. Once again, under the tradeoff theory we would expect a higher interest rate difference to be related to a higher probability of issuing equity and a lower probability of issuing debt.

Finally, the productivity of a firm's assets may also play a role in financing choice. Assets that yield high levels of cash flow are likely to support higher levels of debt than assets that have low cash yields. We measure the cash yield of the REIT by the ratio of its net operating income to its gross property value. The higher this ratio, the higher the cash yield from the firm's assets and the more likely it is to finance with debt.

\section{Other Factors}

We also include a dummy variable equal to one if the firm has public debt outstanding that has been rated by S\&P, according to COMPUSTAT. Having rated debt outstanding could be a sign of lower asymmetric information or could indicate that, because the firm's debt is already a known entity, the firm faces a relatively low transaction cost of going back to the public debt market.

Although we control for the overall effect of leverage, it may be the case that the type of leverage-secured or unsecured-matters. As the vast majority of publicly issued REIT debt is senior unsecured notes, it is logical to expect that the covenants imposed on this type of issuance would affect a firm's choice to issue. Given that unsecured notes are subordinate to secured debt, access to collateral in default is limited to the firm's unencumbered assets. To capture this, we include the ratio of the firm's secured debt to its gross properties. ${ }^{17}$

We also control for firm size using the natural log of the firm's market capitalization taken at the quarter prior to issuance. Given that size could proxy for any number of factors, we do not have a priori expectations for its coefficient.

\footnotetext{
${ }^{17}$ An examination of REIT public debt prospectuses shows that it is also common to place restrictions on the fixedcharge coverage ratio and on total leverage.
} 
Table 7 - Descriptive statistics.

\begin{tabular}{lrrrrr}
\hline \hline Variable & Obs. & Mean & SD & Min. & Max. \\
\hline Price-to-net asset value ratio & 834 & 1.06 & 0.14 & 0.39 & 1.64 \\
Average monthly return & 834 & 1.81 & 1.30 & -4.77 & 5.43 \\
Forecast surprise & 834 & 0.11 & 0.28 & 0.00 & 4.28 \\
Growth & 834 & 7.33 & 2.62 & 0.80 & 19.00 \\
Return of capital (1 = yes) & 834 & 0.60 & 0.49 & 0.00 & 1.00 \\
Leverage & 834 & 45.35 & 10.10 & 14.59 & 90.86 \\
Default spread & 834 & 2.32 & 0.54 & 1.43 & 3.46 \\
Interest rate difference & 834 & -0.54 & 0.83 & -4.96 & 2.03 \\
Net operating income-to-gross-property value & 834 & 9.97 & 1.48 & 5.01 & 15.76 \\
Rated debt outstanding (1= yes) & 834 & 0.75 & 0.43 & 0.00 & 1.00 \\
Sec.-debt-to-gross-property & 834 & 25.64 & 20.14 & 0.00 & 97.65 \\
Size & 834 & 20.73 & 1.04 & 16.75 & 22.96
\end{tabular}

Notes: This table reports descriptive statistics for independent variables. Price-to-NAV ratio is the consensus among equity analysts, and Average monthly return on the firm's equity is computed over the previous year. Growth is the firm's consensus long-term growth estimate, and Leverage is the total debt plus preferred equity divided by total market capital. Default spread is the difference between 10-year BBB and 10-year Treasury rates and Interest rate difference is the firm's weighted average interest rate minus the yield on 10-year BBB debt. Sec.-debt-to-gross-property is the ratio of secured debt to gross property value, and Size is the natural log of the firm's market capitalization. Data are for the period 1997 to 2006.

Table 7 presents the summary statistics for the independent variables used in our analysis. In our sample, the average leverage was $45.35 \%$, and the ratio of secured debt to gross property value averaged $26 \%$. Although both of these variables show significant cross-sectional variation, the averages are in line with the standard wisdom that REITs maintain low leverage.

To ensure that collinearity does not influence our estimation, Table 8 shows the correlations between the independent variables. Almost all these correlations are small-two exceptions being the correlation of -0.68 between the ratio of secured debt to gross property value and the dummy variable for rated debt, and the correlation of 0.57 between size and the presence of rated debt. Table 9 summarizes the empirical predictions for each capital structure theory with respect to the independent variables. 


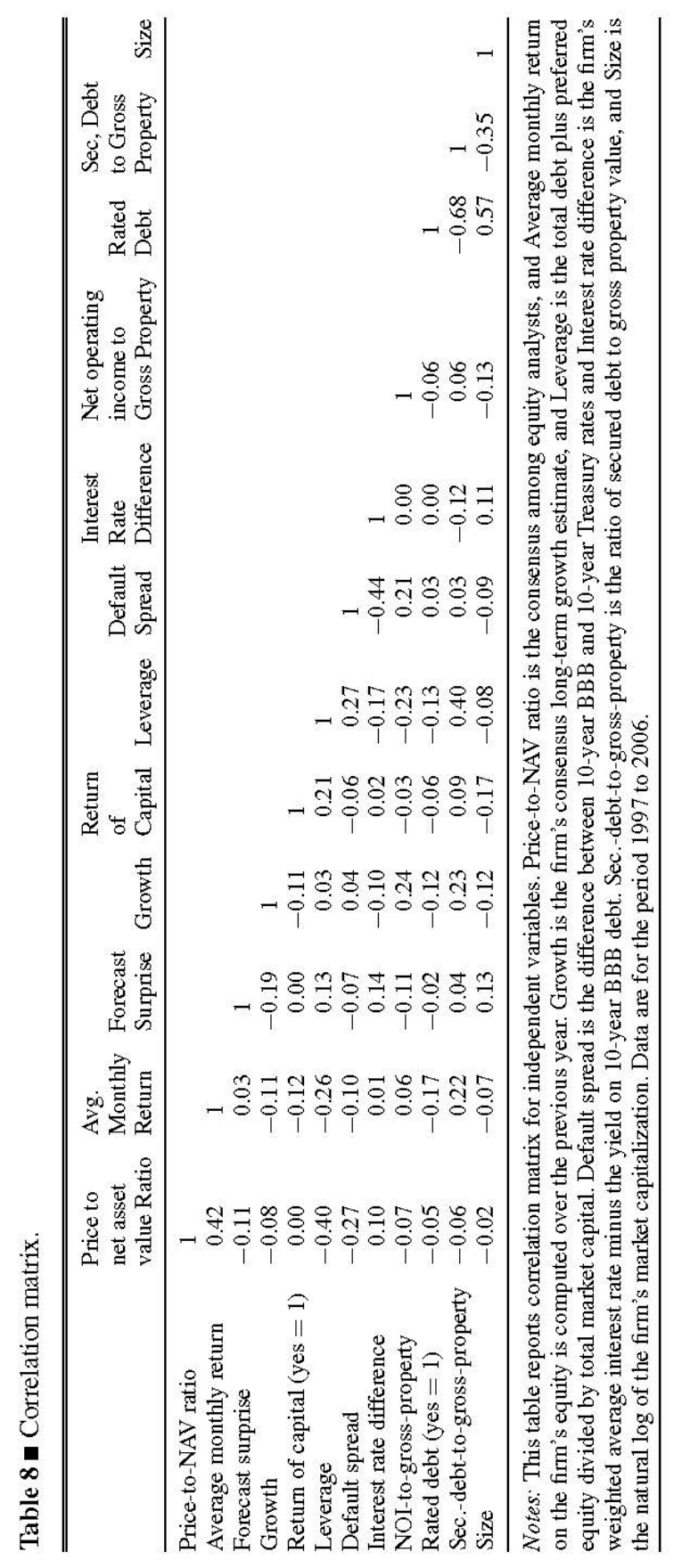


Table 9 Empirical implications of capital structure theories.

\begin{tabular}{|c|c|c|c|}
\hline Variable & Market Timing & Pecking Order & Trade off \\
\hline $\begin{array}{l}\text { Price-to-net asset } \\
\text { value ratio }\end{array}$ & $\begin{array}{l}\text { Increase likelihood } \\
\text { of issuing equity }\end{array}$ & & \\
\hline $\begin{array}{l}\text { Average monthly } \\
\text { return }\end{array}$ & $\begin{array}{l}\text { Increase likelihood } \\
\text { of issuing equity }\end{array}$ & & \\
\hline Forecast surprise & & $\begin{array}{c}\text { Increase likelihood } \\
\text { of issuing debt }\end{array}$ & \\
\hline Growth & & $\begin{array}{c}\text { Increase likelihood } \\
\text { of issuing debt }\end{array}$ & \\
\hline $\begin{array}{l}\text { Return of capital } \\
\quad(\text { yes }=1)\end{array}$ & & $\begin{array}{c}\text { Increase likelihood } \\
\text { of issuing debt }\end{array}$ & \\
\hline Leverage & & & $\begin{array}{l}\text { Decrease (increase) } \\
\text { likelihood of } \\
\text { issuing debt } \\
\text { (equity) }\end{array}$ \\
\hline Default spread & & & $\begin{array}{l}\text { Decrease (increase) } \\
\text { likelihood of } \\
\text { issuing debt } \\
\text { (equity) }\end{array}$ \\
\hline Interest rate difference & & & $\begin{array}{l}\text { Decrease (increase) } \\
\text { likelihood of } \\
\text { issuing debt } \\
\text { (equity) }\end{array}$ \\
\hline $\begin{array}{l}\text { Net operating income- } \\
\text { to-gross-property } \\
\text { ratio }\end{array}$ & & & $\begin{array}{c}\text { Increase likelihood } \\
\text { of issuing debt }\end{array}$ \\
\hline
\end{tabular}

Notes: This table briefly summarizes the key empirical implications of the three major theories of capital structure. Price-to-NAV ratio is the consensus among equity analysts, and Average monthly return on the firm's equity is computed over the previous year. Growth is the firm's consensus long-term growth estimate, and Leverage is the total debt plus preferred equity divided by total market capital. Default spread is the difference between 10-year BBB and 10-year Treasury rates, and Interest rate difference is the firm's weighted average interest rate minus the yield on 10-year BBB debt.

\section{Multinomial Logit Estimation}

We estimate a multinomial logit model with four outcomes: (1) common equity, (2) preferred equity, (3) public debt and (4) private debt. One of the major limitations of the multinomial logit is that the estimated coefficients do not have a direct economic interpretation; in fact, it is possible that, although the coefficient is positive, its marginal effect may be negative. To aid interpretation, we report marginal effects and odds ratios. These estimations include dummy variables for each sample year to capture macro trends and other fixed effects; the coefficients on these estimates are not reported.

Tables 10 and 11 report odds ratios and marginal effects, respectively, for the multinomial logit estimation. Odds ratios in Table 10 are reported as the odds of issuing Alternative 1 over Alternative 2 for a one standard deviation increase in the independent variable heading the column. Marginal effects 
reported in Table 11 are reported as the percentage change in the probability of issuing a given security type for a one standard deviation increase in the independent variable.

The first noticeable result from Tables 10 and 11 is the strong support for the market timing hypothesis. Table 11 reports that a one standard deviation increase in the price-to-NAV ratio and average monthly return leads to a $6.37 \%$ and an $11.24 \%$ increase, respectively, in the probability of issuing common equity. Examining the odds ratios in Table 10, we observe that a one standard deviation increase in average monthly return makes the firm 1.84, 2.21 and 1.48 times more likely to issue common equity than preferred stock, public debt and private debt, respectively. Turning to the price-toNAV ratio, we observe a more complex relationship. A one standard deviation increase in the price-toNAV ratio makes all security types more likely to be issued over private debt, with this being particularly true for common equity. Although the odds ratios between common equity and preferred equity and public debt are greater than one, they are not statistically significant. This result shows that when the price-to-NAV ratio is high, REITs prefer to issue in the public as opposed to the private market.

The three independent variables relating to the pecking order in our analysis are those measuring forecast surprise, growth and the return of capital. Tables 10 and 11 show very weak evidence for the pecking order. First, in terms of both marginal effects and odds ratios, forecast surprise appears to play no role in security choice. If the pecking order provided a strong explanation for issuance behavior we would expect to see a strong preference for debt over equity when forecast surprise increases. There are three potential explanations for these results. First, our analyst-based variables may not be capturing asymmetric information. ${ }^{18}$ As reported in Table 6, REITs appear to have lower levels of forecast surprise compared to similar statistics reported by Gomes and Phillips (2007). The underlying stability of cash flows and tangibility of assets compared to non-REIT firms could make analyst-based measures a poor proxy for asymmetric information in a REIT setting.

A second potential explanation for our result is that using analyst data biases our sample away from very small firms. It is possible that these firms are the firms that face high asymmetric information and as such would be the likely place to find evidence of the pecking order if it does exist. Examining the firms in our sample, we find that the smallest firm has a market capitalization of around \$20 million, with the majority of the sample below $\$ 1$ billion. Comparing to the NYSE market capitalization break points from Kenneth French's Web page, ${ }^{19}$ we see that our sample fits into the mid to lower deciles. This suggests that we do in fact have what would be considered small- to mid-cap firms in our sample. So

\footnotetext{
${ }^{18}$ Best and Best (1995) also use analyst-based measures of asymmetric information and find little evidence for the pecking order.

${ }^{19}$ See http://mba.tuck.dartmouth.edu/pages/faculty/ken.french/data_library.html.
} 
unless the pecking order is confined to microcap stocks, we do not believe our sample should be biased heavily against the pecking order.

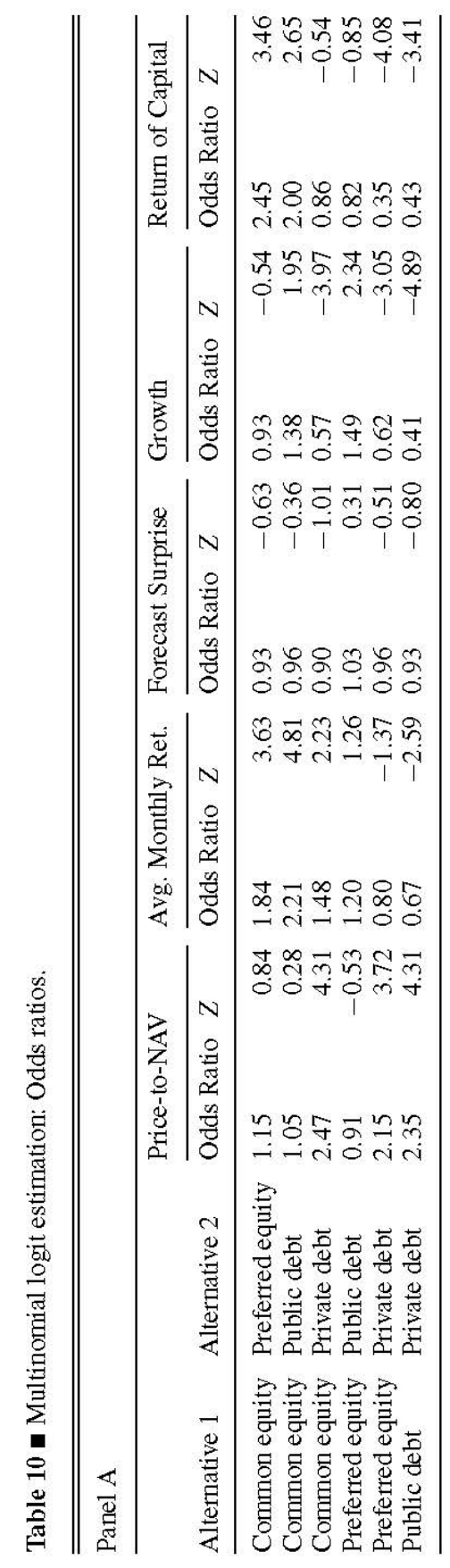




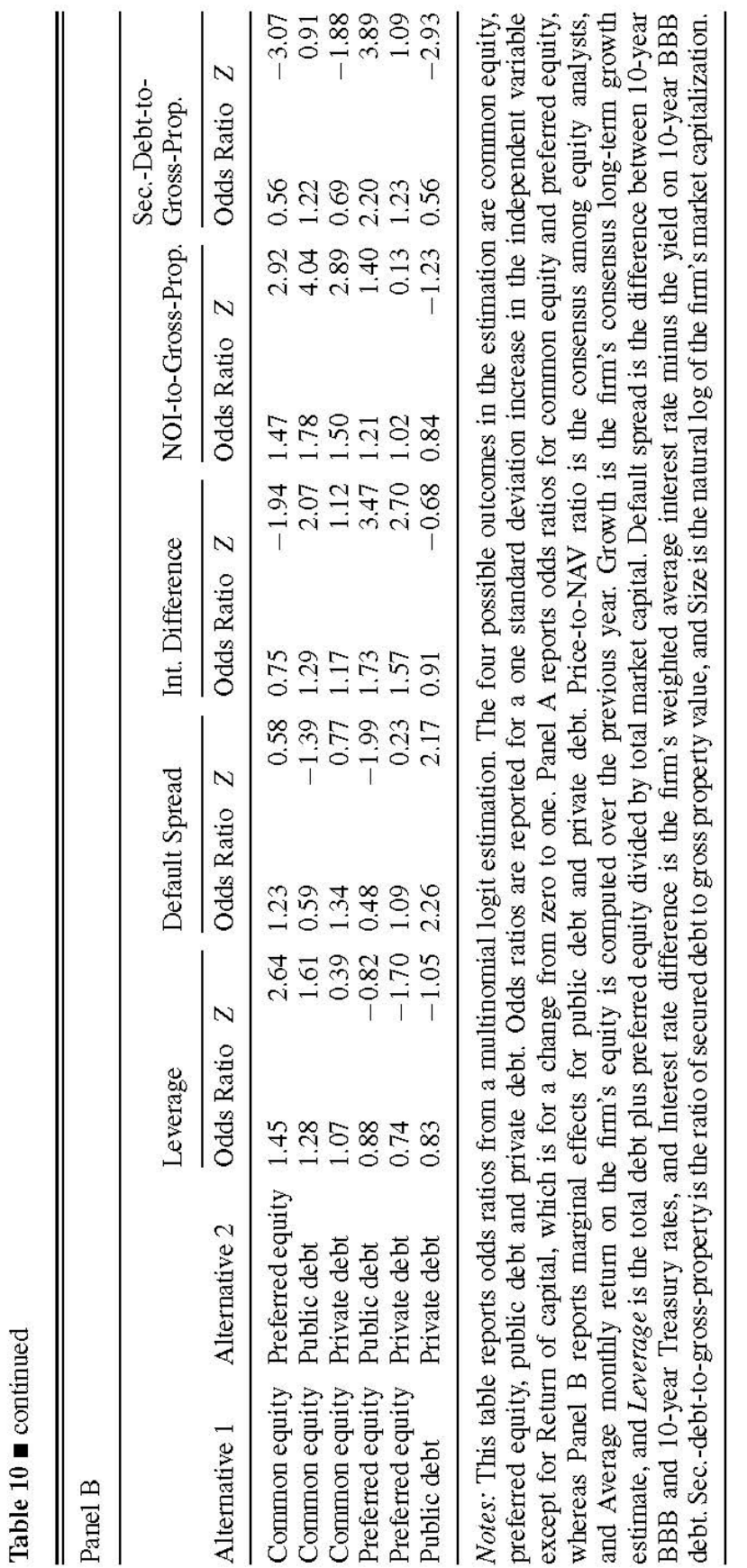


Table 11 aultinomial logit estimation: Marginal effects.

\begin{tabular}{|c|c|c|c|c|}
\hline \multicolumn{5}{|l|}{ Panel A } \\
\hline \multirow[b]{2}{*}{ Variable } & \multicolumn{2}{|c|}{ Common Equity } & \multicolumn{2}{|c|}{ Preferred Equity } \\
\hline & $\begin{array}{l}\text { Change in } \\
\text { Probability }\end{array}$ & $Z$ & $\begin{array}{l}\text { Change in } \\
\text { Probability }\end{array}$ & $Z$ \\
\hline Price-to-net asset value ratio & 6.37 & 2.32 & 3.79 & 1.18 \\
\hline Average monthly return & 11.24 & 4.2 & -5.72 & -1.93 \\
\hline Forecast surprise & -1.43 & -0.73 & 0.52 & 0.3 \\
\hline Growth & -2.09 & -0.98 & -0.33 & -0.12 \\
\hline Return of capital & 10.17 & 2.6 & -15.70 & -3.55 \\
\hline Leverage & 4.81 & 2.09 & -6.28 & -2.22 \\
\hline Default spread & 0.80 & 0.14 & -5.84 & -0.88 \\
\hline Interest rate difference & -0.36 & -0.18 & 9.01 & 3.08 \\
\hline Net operating income-to-gross-properties & 8.34 & 3.94 & -1.97 & -0.81 \\
\hline Rated & -21.80 & -2.74 & 6.73 & 1.06 \\
\hline Sec-debt-to-gross-prop. & -6.15 & -1.94 & 11.71 & 3.4 \\
\hline Size & -14.92 & -5.97 & -5.60 & -1.89 \\
\hline \multicolumn{5}{|l|}{ Pane1 B: Debt Issues } \\
\hline & \multicolumn{2}{|l|}{ Public Debt } & \multicolumn{2}{|l|}{ Private Debt } \\
\hline Price-to-NAV ratio & 3.89 & 1.7 & -14.05 & -4.8 \\
\hline Average monthly return & -6.67 & -3.16 & 1.15 & 0.49 \\
\hline Forecast surprise & -0.27 & -0.21 & 1.18 & 1.05 \\
\hline Growth & -7.78 & -2.97 & 10.20 & 4.75 \\
\hline Return of capital & -5.16 & -1.65 & 11.54 & 3.4 \\
\hline Leverage & -1.16 & -0.58 & 2.63 & 1.01 \\
\hline Default spread & 10.62 & 2.09 & -5.58 & -1.04 \\
\hline Interest rate difference & -5.00 & -2.9 & -3.65 & -1.72 \\
\hline NOI-to-gross-properties & -4.74 & -2.45 & -1.63 & -0.83 \\
\hline Rated & 33.00 & 9.89 & -17.95 & -2.5 \\
\hline Sec-debt-to-gross-prop. & -8.46 & -3.09 & 2.90 & 1.07 \\
\hline Size & 11.24 & 4.51 & 9.28 & 3.6 \\
\hline No. of obs. & 834 & & & \\
\hline Wald $\chi^{2}$ & 256.7 & & & \\
\hline Psuedo- $R^{2}$ & 0.23 & & & \\
\hline
\end{tabular}

Notes: This table reports the change in probability of each outcome for a one standard deviation increase in the dependent variable. For dummy variables the change in probability is for an increase from zero to one. The four possible outcomes in the estimation are common equity, preferred equity, public debt and private debt. Odds ratios are reported for a one standard deviation increase in the independent variable except for Return of capital, which is for a change from zero to one. Panel A reports odds ratios for common equity and preferred equity, whereas Panel B reports marginal effects for public debt and private debt. Price-to-NAV ratio is the consensus among equity analysts, and Average monthly return on the firm's equity is computed over the previous year. Growth is the firm's consensus long-term growth estimate, and Leverage is the total debt plus preferred equity divided by total market capital. Default spread is the difference between 10-year BBB and 10-year treasury rates, and Interest rate difference is the firm's weighted average interest rate minus the yield on 10-year BBB debt. Sec.-debt-to-gross-property is the ratio of secured debt to gross property value, and Size is the natural log of the firm's market capitalization.

Finally, it is possible that the effects of other variables in our estimation are swamping our asymmetric information proxy. One could interpret firm size as a measure of asymmetric information. It is plausible to think that, holding industry constant, larger firms should have less asymmetric information than smaller firms; for example, it is well known that larger firms have higher analyst coverage and higher institutional ownership. If this is the case, we would expect large firms (those that have low asymmetric information) to issue more equity, because the pecking order should play less of a 
role for these firms. We would also expect small firms to issue debt. The marginal effects reported in Table 11 for firm size run counter to this interpretation in all cases.

Dynamic versions of the pecking order suggest that, when growth options are high, the firm should stockpile debt by issuing equity. We can directly examine this using the odds ratios in Table 10. The odds ratios between private debt and the other security types show a distinct preference for private debt as the growth rate increases. This runs counter to our notion of stockpiling debt.

Examining the variable indicating return of capital, we observe strong evidence against the pecking order. Firms that return capital appear to have a strong preference to issue common equity and private debt over public debt and preferred equity. Although the relationship between private debt and preferred equity and public debt is consistent with the pecking order, the result for common equity clearly violates it. If the pecking order holds, then firms should not return capital and then issue common equity. This relationship is also evident in the marginal effects reported in Table 11, where firms that return capital are $10.17 \%$ more likely to issue equity.

Turning to trade-off theory, we find mixed evidence in Tables 10 and 11. The four variables related to trade-off theory are the leverage ratio, the default spread, the interest rate difference and the ratio of net operating income (NOI) to gross property value. The leverage ratio provides some support for trade-off theory with a positive marginal effect on common equity in Table 11. Examining odds ratios in Table 10, we see that this trade-off is largely one between common equity and preferred equity. Although issuing common equity over preferred could be considered leverage decreasing, it would not be the most efficient way of doing this. So, although the relationship goes in the direction suggested by trade-off theory, we do not interpret it as strong support.

Higher levels of default spread and interest rate differences suggest higher potential bankruptcy costs and trade-off theory suggests that this should lead to a decrease in leverage. Tables 10 and 11 show contradictory evidence for the default spread: both marginal effects and odds ratios show that firms are more likely to issue public debt when the default spread increases. The evidence provided by the interest rate difference is more supportive of the trade-off theory. For increases in interest rate difference, Table 10 shows that firms are more likely to issue common equity over public debt and preferred equity over any kind of debt, with the latter relationship quite strong with odds ratios of 1.73 and 1.57 .

The last measure related to the trade-off theory is the ratio of NOI to gross property value. Assets that have higher cash yields should be able to support higher levels of debt, so we would expect to see a positive relationship between the NOI-to-gross-property ratio and debt issuances. Tables 10 and 
11 show the exact opposite is true in the data: there is a strong preference to issue common equity when the NOI-to-gross-property ratio is greater.

The odds ratios and marginal effects in Tables 10 and 11 for the ratio of secured debt to gross property value leads to an interesting observation. When considering capital structure, typically little thought is given to the type of debt that a given firm has. When examining leverage at the issuance level, the interaction of the firm's current capital structure and the characteristics of the issuance may play an important role in the ability of the firm to issue that security. As the public debt market for REITs is dominated by senior unsecured notes, it is intuitive to expect that the level of secured debt may play a role in the firm's ability to issue more public debt. Controlling for overall leverage, firms with few unencumbered assets are less likely to be able to issue public debt because it is these unencumbered assets that are effectively securing the senior unsecured debt in default. Examining the odds ratios and marginal effects, we see that this is the case: firms are more likely to issue preferred equity or private debt over public debt when the level of secured debt in the firm is high.

Overall, our results are supportive of the market timing hypothesis. Our evidence for the tradeoff theory is mixed at best, although we find very little support for the pecking order.

\section{Conclusion}

This study examines the role that traditional capital structure theories play in the security issuance decisions of REITs. Although these theories have received a great deal of attention in the finance literature, the unique characteristics of REITs make it unclear how well these results apply to REITs. As REITs are effectively tax exempt at the corporate level, tax-based motivations for issuing securities are ruled out. REIT restrictions on dividend payout means that free cash flow motivations are also unlikely to play a significant role in security issuances. REITs also represent a fairly transparent investment vehicle, so it is difficult to argue that REIT investors face a high level of asymmetric information. It has been argued (see Feng, Ghosh and Sirmans 2007) that real estate trades in an illiquid secondary market, but this needs to be compared to non-REIT firms whose assets do not trade in any secondary market. The simple fact that analysts can estimate the NAV of a REIT, or even bother to do so, implies a degree of asset transparency that does not occur in non-REIT firms. This transparency mitigates to a large degree the applicability of pecking-order motivations to issue securities (see Myers 1984, Myers and Majluf 1984).

Examining a sample of 96 equity REITs making 834 security issuances between 1997 and 2006, we find that REITs appear to try to time the market. They do this in two ways. First, REITs are more likely 
to issue equity after high past returns. This is consistent with conventional market timing theories and suggests that REITs try to time the public equity market. Second, REITs also attempt to time the price differentials between public and private equity markets. Controlling for growth and past returns, a high price-to-NAV ratio suggests that the REIT will be more likely to issue equity in the public market. Notice, however, that there is no behavioral motivation underlying this result. Managers are not issuing public equity because they believe it is overvalued, but simply because it is cheaper compared to private equity.

Our second result is that we find some support for the trade-off theory: REITs consistently appear to shy away from debt and toward equity when expected bankruptcy costs are high. Third, we find little support for either static or dynamic versions of the pecking-order theory. Our analyst-based measures of asymmetric information do not drive security issuances in the direction predicted by the pecking order. Furthermore, other variables related to the pecking order provide little corroborative evidence. Firms that return capital are more likely to issue equity, and firms with high growth options do not appear to consistently stockpile debt capacity.

Finally, our results relating to preferred stock issuance offer some insights beyond an examination of capital structure theories. Although from a theoretical perspective there is little guidance as to the drivers of preferred equity issuances for tax-exempt firms, the decisions to issue equity and preferred equity appear to be quite different. A high price-to-NAV ratio has an insignificant effect, and past market returns decrease the probability of issuing preferred equity; when the costs of issuing debt are high, however, REITs are more likely to issue preferred equity.

Overall, our results suggest that REIT issuance decisions are largely driven by market timing motivations. REITs try to time the public and private equity markets and stay away from the debt market when the expected costs of bankruptcy are high. These findings suggest that the unique characteristics of REITs make the capital structure decision differ significantly from that of a non-REIT corporation. The relatively greater importance of preferred stock in REIT capital structure is an example of this.

\section{References}

Baker, M. and J. Wurgler. 2002. Market Timing and Capital Structure. The Journal of Finance 62: 1-32. Best, R. and R. Best. 1995. An Empirical Analysis of Cross-Security Information Asymmetry and the 'Pecking Order Hypothesis.' Journal of Economics and Finance 19: 19-29.

Bharath, S.T., P. Pasquariello and G. Wu. 2009. Does Asymmetric Information Drive Capital Structure Decisions? Review of Financial Studies 22: 3211-3243. 
Boudry, W.I. 2009. Who Returns Capital? An Examination of REIT Dividend Payout Policy. Working Paper. University of North Carolina-Chapel Hill.

Damodaran, A. and C.H. Liu. 1993. Insider Trading as a Signal of Private Information. Review of Financial Studies 6: 79-119.

Downs, D.H. and Z.N. Gunner. 1999. Is the Information Deficiency in Real Estate Evident in Public Market Trading? Real Estate Economics 27: 517-541.

Fama, E. and K. French. 2002. Testing Trade-Off and Pecking Order Predictions about Dividends and Debt. Review of Financial Studies 15: 1-33.

Feng, Z., C. Ghosh and C.F. Sirmans. 2007. On the Capital Structure of Real Estate Investment Trusts (REITs). The Journal of Real Estate Finance and Economics 34: 81- 105.

Fisher, E.O., R. Heinkel and J. Zender. 1989. Dynamic Capital Structure Choice: Theory and Tests. The Journal of Finance 44: 19-40.

Frank, M.Z. and V.K. Goyal. 2003. Testing the Pecking Order Theory of Capital Structure. Journal of Financial Economics 67: 217-248.

Garmaise, M.J. and T.J. Moskowitz. 2004. Confronting Information Asymmetries: Evidence from Real Estate Markets. Review of Financial Studies 17: 405-437.

Gentry, W.M. and C.J. Mayer. 2002. What Can We Learn about Investment and Capital Structure with a Better Measure of q? Working Paper. Columbia University.

Gomes, A. and G. Phillips. 2007. Private and Public Security Issuance by Public Firms: The Role of Asymmetric Information. Working Paper. University of Maryland.

Graham, J.R. and C.R. Harvey. 2001. The Theory and Practice of Corporate Finance: Evidence from the Field. Journal of Financial Economics 60: 187-243.

Han, B. 2006. Inside Ownership and Firm Value: Evidence from Real Estate Investment Trusts. The Journal of Real Estate Finance and Economics 32: 471-493.

Hausman, J. and D. McFadden. 1984. Specification Tests for the Multinomial Logit Model. Econometrica 52: 1219-1240.

Heinkel, R. and J. Zechner. 1990. The Role of Debt and Preferred Stock as a Solution to Adverse Investment Incentives. Journal of Financial and Quantitative Analysis 25: 1-24.

Howe, J.S. and J.D. Shilling. 1988. Capital Structure Theory and REIT Security Offerings. The Journal of Finance 43: 983-993.

Jaffe, J.F. 1991. Taxes and the Capital Structure of Partnerships, REIT's, and Related Entities. The Journal of Finance 46: 401-407. 
Jensen, M.C. 1986. Agency Costs of Free Cash Flow, Corporate Finance and Takeovers. American Economic Review 76: 323-329.

Ju, N., R. Parino, A. Poteshman and M. Weisbach. 2002. Horses and Rabbits? Optimal Dynamic Capital Structure from Shareholder and Manager Perspectives. NBER Working Paper No. 9327.

Lang, M.H. and R.J. Lundholm. 1996. Corporate Disclosure Policy and Analyst Behavior. Accounting Review 71: 467-492.

Lemmon, M.L. and J.F. Zender. 2004. Debt Capacity and Tests of Capital Structure Theories. Working Paper. University of Colorado at Boulder.

Mikhail, M.B., P. Asquith and A. Au. 2005. Information Content of Equity Analyst Reports. Journal of Financial Economics 75: 245-282.

Modigliani, F. and M.H. Miller. 1958. The Cost of Capital, Corporation Finance, and the Theory of Investment. American Economic Review 48: 655-669.

Myers, S.C. 1984. The Capital Structure Puzzle. The Journal of Finance 39: 575- 592.

Myers, S.C. and N.S. Majluf. 1984. Corporate Financing and Investment Decisions When Firms Have Information that Investors Do Not Have. Journal of Financial Economics 13: 187-221.

Ott, S., T. Riddiough and H. Yi. 2005. Finance, Investment and Investment Performance: Evidence from the REIT Sector. Real Estate Economics 33: 203-235.

Ross, S.A. 1977. The Determination of Financial Structure: The Incentive-Signaling Approach. The Bell Journal of Economics 8: 23-40.

Shyam-Sunder, L. and S.C. Myers. 1999. Testing Static Tradeoff versus Pecking Order Models of Capital Structure. Journal of Financial Economics 51: 219-244.

Welch, I. 2004. Capital Structure and Stock Returns. Journal of Political Economy 102: 106-131. 